\title{
A FRAMEWORK FOR UNDERSTANDING CHARTER SCHOOL ACCOUNTABILITY
}

\author{
GREGG GARN \\ University of Oklahoma \\ CASEY D. COBB \\ University of New Hampshire
}

Since their inception, publicly funded schools in the United States have been answerable to the communities they serve. Traditionally, locally elected school boards served as the primary watchdog. However, during the middle of the past century, dramatic increases in student enrollments brought with them a heightened level of public scrutiny over the role and performance of schools. Legislators and policy makers at all levels increased the rigor and visibility of public school accountability.

Today, schools are being asked to demonstrate their quality to multiple constituencies, including parents, board members, legislators, and the general public. In particular, state oversight has taken on a more aggressive tone. Numerous reforms-from mandatory teacher and student testing to takeovers of failing schools-are being implemented to ensure that schools are accountable for the public funds they receive.

Advocates of the charter school movement frequently argue that increased accountability is a fundamental component of this reform. Indeed, it is fairly typical to find some variation of the phrase "to establish new forms of accountability for schools" listed among the major purposes of a state's charter law. At the same time, however, critics of the reform posit that charter schools lack even the most basic of accountability checks. An exchange between Mary Hartley and Jeffrey Flake in the Arizona Republic newspaper illustrated the confusion surrounding such accountability rhetoric.

Democratic Senator Mary Hartley articulated one perspective on charter school accountability in an August 20,1995, editorial:

Arizona's charter schools are not the models of academic and fiscal accountability that [proponents] make them out to be. There is little taxpayer accountability for the public funds between the time the charter application is approved 
and the renewal application deadline five [now 15] years later. Only a handful of staff people at the State Department of Education will monitor the activities of these schools.... What taxpayer would allow any other governmental entity to spend $\$ 100$ million that these schools will need over the next five years without any oversight or accountability? (p. E3)

Flake, executive director of the Goldwater Institute and a proponent of school choice, presented his view of accountability in an editorial response to Hartley in the Arizona Republic on August 26, 1995:

To believe that charter schools, which enroll children who are there by choice, are less accountable than mainstream public schools, which enroll children who have no choice, is to have an odd view of accountability. If the goal is for schools to be accountable to district governing boards, superintendents or state bureaucrats, then we may want to stick to the old public-school model. If, however, the goal is to have schools accountable to actual customers of education (students and parents), charter schools are long overdue. ... If at any time the parent is unsatisfied with the education [at a charter] the child can be removed and placed elsewhere. That's accountability! (p. B6)

In this article, we explore various dimensions of charter school accountability. In the end, three models of educational accountability derived from the literature were used as a basis to assess state policies on charter school accountability. It became evident that states place varying degrees of emphasis on these three forms of accountability. The implications of relying on particular models of accountability are discussed.

\section{THE NATURE OF THE CHARTER SCHOOL}

The history of charter schools is relatively brief, dating back only 25 years. The concept can be traced to a 1974 paper titled "Education by Charter: Key to a New Model of School District." Presented at the General Systems Research Society national meeting, this paper had little effect on public education (Budde, 1988). However, it did provide the intellectual spark for Ray Budde, the individual generally given credit for conceiving the charter school concept.

Budde, a professor of education at the University of Massachusetts, published a book in 1988 entitled Education by Charter: Restructuring School Districts, Key to Long-term Continuing Improvement in American Edu- 
cation. The book justified and laid out a plan for radical reform in education and then explained how to implement it. Budde asserted that "nothing short of fundamental change in the organization of the school district will sustain and incorporate needed reforms" (p. i). Soon afterward, Albert Shanker, former president of the American Federation of Teachers (AFT), gave public support to Budde's proposal (Shanker, 1988, p. 98).

Joe Nathan, the director of the Center for School Change at the University of Minnesota's Humphrey Institute of Public Affairs, subsequently moved this idea toward practice. Along with fellow Minnesotan Ted Kolderie, a senior associate at the Center for Policy Studies, Nathan spoke of the merits of the charter concept and persuaded policy makers to adopt the reform. Other individuals and organizations from across the country continued to refine and alter the charter school idea.

Although the basic concept of the charter contract remains intact, there is still room for states to find other ways of monitoring their charter schools. Indeed, states construct their own meanings of accountability. Because of the important differences across the 37 state charter statutes and the various ways in which the accountability concept can be construed, we begin with a brief review of the relevant literature to understand more precisely the types of accountability by which charter schools may be bound.

\section{MULTIPLE CONCEPTIONS OF ACCOUNTABILITY}

Levin (1974) captured the ambiguity associated with the concept of educational accountability:

The similarities underlying the great diversity in the use of the word accountability are not readily obvious. Questions are raised as to whether each of these [definitions] is an application of the same concept, or whether these different applications represent different animals per se. (pp. 363-364)

The accountability literature bears out Levin's claim of diverse conceptualizations. Glass (1972) stated that accountability was rooted in

the simple economic relationship of vendor and buyer ... and involves three elements: 1) disclosure concerning the product or service being sold, 2) product or performance testing, 3 ) redress in the event of false disclosure or poor performance. (p. 637) 


\section{Winthrop (1975) claimed that}

the most general meaning attached to the concept of accountability is that schools at all levels are responsible for imparting chiefly the reading and mathematical skills needed to fulfill the requirements of almost any job or profession, plus any other elementary skills that may be essential. The second and more sophisticated meaning of accountability refers to the question of whether the educational system at the secondary and academic levels-chiefly the academic level-imparts the knowledge and skills needed for (1) intelligent citizenship and (2) a variety of the policy making and planning professions. (p. 127)

Wohlstetter (1991), on the other hand, contended that

an accountability mechanism in education is defined as a body or group that uses educational indicators to track the progress of education policy. . . . Its function is to oversee (monitor and evaluate) the performance of the education system and to propose needed changes to policy makers. (p. 33)

Finally, Gintis (1995) provided this straightforward definition: "Quantitative measures of the performance of participating schools are maintained and disseminated to the public" (p. 492).

From these broad and varied definitions stemmed a number of more precise forms of accountability. These include: (a) performance reporting, (b) technical process, (c) political process, and (d) institutional process (Levin, 1974, p. 364); (e) state or public control, (f) professional control, and (g) consumer control (Kogan, 1986, as cited by House, 1993, p. 35); (h) legal, (i) bureaucratic, (j) professional, and (k) market (Darling-Hammond, 1989, p. 61); and (l) monitoring and compliance with standards or regulations, (m) incentive systems, and ( $\mathrm{n}$ ) changing the locus of control (Kirst, 1990, pp. 710). The multiple meanings identified in the literature illuminate the complexity involved in holding our public educational institutions accountable.

\section{UNDERSTANDING CHARTER SCHOOL ACCOUNTABILITY}

Our attempts to disentangle the multiple meanings embodied within this seemingly monolithic term proved to be a challenge. Ultimately, we constructed a more simplified conceptual framework to better understand charter school accountability. From the 14 different types of accountability we 
identified in the literature, we selected three models that are particularly relevant to charter schools: bureaucratic, performance, and market accountability. Below, we describe and briefly critique each of these models.

Darling-Hammond (1988) defined bureaucratic accountability as "agencies of government which promulgate rules and regulations intended to assure citizens that public functions will be carried out in pursuit of public goals voiced through democratic or legal processes" (p. 9). She argued that bureaucratic mechanisms work best when

a standard set of practices or procedures can be easily linked to behavioral rules that will produce the desired outcomes. ... [It] does not guarantee results, it concerns itself with procedures; it is effective only when procedures are known to produce the desired outcomes and when compliance is easily measured and secured. (p. 10)

However, rarely in the history of public education has there been widespread agreement about desired educational outcomes, a fact that has confounded bureaucratic accountability mechanisms. Another problem associated with bureaucratic accountability has been the time required to document compliance with rules and regulations. Many school bureaucrats work fulltime dealing with procedural compliance issues, thereby diverting resources from direct classroom instruction. Regardless of the strengths and weaknesses of bureaucratic accountability, this type has been the dominant form of accountability associated with public education over the past several decades.

In contrast to the focus on inputs in bureaucratic accountability, performance accountability is concerned with outputs. Levin (1974) defined performance accountability as "a periodic report of the attainments of schools and other educational units" (p. 364). Similarly, the Federal Office of Educational Research and Improvement defined it as "a set of indicators or statistics that provides information about how well schools are performing" (as cited by Rivera, 1994, p. 7). Kirst (1990), however, added that

performance reporting includes such measurement techniques as statewide assessment, National Assessment of Educational Progress (NAEP), school report cards, and performance indicators, and it has some similarities to the audit report in business. In essence, performance reports assume that information per se will stimulate actions to improve education. . . . Also, state performance reporting can be used to monitor regulatory compliance for such state requirements as minimum graduation requirements. ... This technique can be used to produce rewards as well as sanctions. (pp. 7-8) 
In theory, performance indicators should lead to a more accurate understanding of the strengths and weaknesses of a given school. Levin (1974) argued that the "presumption underlying the performance reporting interpretation is that information on educational outcomes is necessary to enable constituents to appraise the proficiencies of the schools" (p. 364). Objective observers could make decisions about rewards and punishments earned by the schools based on performance criteria.

Performance accountability has its own set of flaws, however. Problems center on the design of instruments that reliably and validly measure student achievement (Rivera, 1994, p. 12). Many researchers (e.g., Smith, 1988) have argued that the use of performance indicators, such as standardized tests, could lead to a narrowing of the curriculum and also result in unfair comparisons between schools. Others contend that although standardized tests may foster the acquisition of basic skills, they place little emphasis on higher order levels of thinking. Dorn (1998) assessed the practical legacy of testing: "Despite considerable evidence that high stakes testing distorts teaching and does not give very stable information about student performance, test results have become the dominant way states, politicians and newspapers describe the performance of schools" (p. 4). Dorn also argued that using test scores to evaluate schools treated schools as a "monolithic entity ... and hides wide variations in schooling, especially between poor and wealthy schools" (p. 4). Cronbach (1991), however, "doubts that [this type of performance] accountability enhances efficiency or that program goals are clear and widely agreed upon" (p. 351). Campbell (1991, as cited by Shadish, Cook, \& Leviton, 1991) also believed there were weaknesses in this type of accountability:

[Campbell] stressed the need for multiple single indicators, all recognized as partially imperfect and partially relevant. He also claimed that indicators will change in validity once they become the focus of decision making. ... The more any social indicator is used for social decision making, the greater the corruption pressures upon it. (p. 141)

Kirst (1990) questioned "whether performance reports alone lead to much change in either citizen or professional educator behavior" (p. 10). Similarly, Levin (1974) challenged the fundamental presumptions of performance accountability:

First, there is a tacit assumption that there is unanimity on the objectives of education and the information provided will be useful to all of the constituencies with educational concerns.... A second question raised by accountability as 
performance reporting is how the mere provision of information will provide results. (p. 365)

The third model of accountability included in our framework, and one that is particularly relevant to charter schools, involves consumer control. Kirst (1990) stated that "[market] accountability occurs when consumers choose between schools, with the bad schools presumably closing if the pupils leave" (p. 9). He also maintained that "choice restricted to the public sector may not be a powerful accountability device" (p. 23). Darling-Hammond (1988) described market accountability as one in which

governments may choose to allow clients or consumers to choose what services best meet their needs; to preserve the utility of this form of accountability, government regulations seek to prevent monopolies, protect freedom of choice, and require that service providers give truthful information. (p. 10)

Furthermore, Darling-Hammond (1988) emphasized the strengths of this form of accountability: "[Market accountability mechanisms] are helpful when consumer preferences vary widely, when the state does not have a direct interest in controlling choice and when government control would be counter productive to innovation" (p. 11).

Chubb and Moe (1988) refined the marketplace accountability argument as it applied to public schools. They maintained that if parents had a choice among public and private schools, the performance levels would rise, as competition would require schools to compete for their student populations.

However, this form of accountability can be problematic, in that "market accountability does not ensure citizens' access to services and relies on the spontaneous emergence of a variety of services to allow choice to operate as a safety valve for poor service provision" (Darling-Hammond, 1988, p. 11). Glass (1972) maintained that the market mechanism in schooling "provides in no clear manner for disclosure by the schools to the public of either its operation or its goals, nor does it provide for the assessment of the performance of the schools" (p. 638).

Market accountability could lead to a narrow definition of success by consumers. For example, parents could keep their children in a school that lacked a mathematics curriculum. If the children were happy and the parents were satisfied, regardless of the degree and breadth of learning that took place, market accountability mechanisms would be fulfilled. In reality, few marketbased accountability systems have been set up for public education and, consequently, support for this form of educational accountability has been grounded in economic theories rather than by empirical evidence. 
These models of accountability are not perfect, and they likely will never be perfect. We will always have difficulty establishing clear and worthy criteria on which to judge schools. For these accountability models to work better, however, certain things must be in place. For instance, it can be argued that for market and/or performance accountability to be effective, there need to be valid and reliable indicators of school quality made available to all consumers of public education. For bureaucratic accountability to work, the right collection of inputs has to be identified, and there have to be sufficient resources available to monitor them effectively.

\section{CHARTER SCHOOLS: A SHIFT IN ACCOUNTABILITY EMPHASIS}

Public schools have long been held accountable predominantly by way of bureaucratic controls, less so by performance, and even less so by market controls. The emphasis on bureaucratic inputs has, however, been giving way to performance indicators over the past decade or so (witness the increased use and visibility of test scores, report cards, and the like). Market accountability has always been present in traditional public schools, though in less obvious ways. In one form-by way of parental choice-it has been restricted to those that have the means and the wherewithal to move to a district of their choice. Competition finds its way in the public school arena in other ways. For instance, municipalities that have no high school may "tuition out" their middle school students to district secondary schools of their choosing (a pseudovoucher system).

The contrasting perspectives presented toward the beginning of this article illustrate how the charter school concept can be construed as more and less accountable than traditional forms of public school accountability. Those that say charter schools are more accountable evidence the strong competitive component (market accountability). Compare this form of accountability with district public schools, which have predominantly relied on bureaucratic and (to an increasing but lesser degree) performance forms of accountability. Charter schools are bound by a written contract with a sponsoring agency, and the covenant is simple-achieve specific goals in a set time period, while attracting and maintaining pupil enrollment, in exchange for a blanket waiver from bureaucratic reporting. Clearly-by its own definition-the charter school concept de-emphasizes bureaucratic accountability in favor of a market-based one (see Figure 1). Critics of the charter concept cite this very same market feature as reason that charter schools are actually less account- 


$\begin{array}{ll}\text { Traditional Concept } & \text { Charter Concept } \\ \text { BUREAUCRATIC } & \text { BUREAUCRATIC } \\ \text { PERFORMANCE } & \text { PERFORMANCE } \\ \text { MARKET } & \text { MARKET }\end{array}$

\footnotetext{
Figure 1: The Emphasis on Three Models of Accountability Between Traditional Public Schools and Charter Schools
}

able. They appeal to the overreliance on a single form of accountability; furthermore, critics contend that this model of accountability is of questionable application in the public arena of schooling.

We should point out that Figure 1 is actually a theoretical generalization about charter schools. That is, in theory, charter schools are supposed to add a substantial market component. However, upon closer inspection of state charter laws, states differ in the degree to which they emphasize bureaucratic, performance, and market forms of accountability. It may be that the charter school concept calls for a greater (and predominant) emphasis on market accountability, but a complete analysis of state laws belies this theoretical notion.

\section{AN ANALYSIS OF THREE STATES}

We illustrate the ways that states emphasize these forms of accountability by way of three examples. These three exemplary cases emerged from our initial inspection of charter school legislation from all 37 states. Our subsequent analysis focused on the types of accountability that were embedded in the legislation of three states. Working independently, we read through and coded, line by line, the charter school legislation for each of these three states. The theoretical framework (which included market, bureaucratic, and 
performance accountability) structured the anticipatory data reduction process. We then compared the results of the independent analyses. The strategy for analyzing the documents followed Glasser and Strauss's (1967) constant comparative method, as well as Miles and Huberman's (1994) approaches to coding, displaying, analyzing, and verifying data.

\section{THE WILD WEST: ARIZONA}

Leading policy makers in Arizona theorized that moving to a marketdriven system would ensure greater levels of accountability. Tom Patterson, a primary sponsor of the charter legislation in the Arizona State Senate, maintained that

charter schools are in a way a test of an entirely different accountability method which is decentralized, which depends, rather than on bureaucratic rules and regulations, on first of all these being schools of choice. It's accountability that comes from the parents and the consumers. (personal communication, March $16,1998)$

When putting this theory into practice, authors of the Arizona charter school legislation included several key provisions to encourage the development of a charter school market. First, they established multiple charter school authorizers: the State Board of Education (SBE), the State Board for Charter Schools (SBCS), and the Board of Education for a public school district (Arizona Revised Statute, 2000, §15-183C). Second, they placed no limit on the total number of charter schools that could open each year and allowed multiple sites to spawn from a single charter (\$15-183C2). Third, they allowed any individual or group (private or public) to operate a charter school ( $\$ 15-183 B)$. Fourth, they created a 15-year contract between the charter school and the sponsor ( $15-183 I)$. Fifth, they exempted charter schools from the statutes and rules relating to schools, governing boards, and school districts (\$15-183E5). Sixth, they allowed charter school operators to own the property purchased for the school $(\S 15-183 \mathrm{U})$. Finally, they provided charter schools with complete financial (\$15-185) and legal (\$15-183D) autonomy. These key provisions in the legislation provided the freedom from regulations and the autonomy to innovate that appealed to many educational entrepreneurs (Garn, 2000). By the 1999-2000 school year, 348 charter school sites were operating in the state, approximately $21 \%$ of the national 
total (Center for Education Reform, 2000). By all accounts, policy makers were successful in creating additional choices for parents and students.

\section{THE BUREAUCRATIC BEHEMOTH: KANSAS}

In Kansas, the charter school reform took on a very different look. In fact, you have to look closely to tell a charter school apart from a district school. For instance, one section requires that only local school boards can sponsor new charter schools and leaves no outlet for applicants who are rejected (Kansas Revised Statute, 2000, \$72-1904). Moreover, there are severe limits on the number of charter schools that can be approved in the entire state in a single year (15) and that can be operated by a single district (2) (\$72-1905). The language of the statute is particularly telling in section $72-1906 \mathrm{C} 5$, which describes that the charter contract must contain "the governance structure of the school, including the means of ensuring accountability to the board of education [italics added]." The state also requires applicants to describe the pupil suspension and expulsion policies "to the extent that there is deviation from districtwide policies" (\$72-1906C10). In other words, charter schools in Kansas are held to the same bureaucratic accountability standard as district schools.

The Kansas legislation includes an additional layer of bureaucratic entanglement absent in most other charter school laws. Section 72-1906E requires that after the local school board has approved the application for a new school, the Kansas State Board of Education "shall determine whether the charter school is in compliance with state and federal laws and rules and regulations. If the charter school is found to be in compliance with such laws and rules and regulations, the state board shall approve establishment of the charter school."

Section $72-1906 \mathrm{C} 14$ requires charter school officials to petition for a waiver from specific rules and regulations. Rather than a blanket waiver described in most states' charter school legislation, in Kansas, a justification for specific bureaucratic reporting exemptions must be included in the charter. Once again, board members and bureaucrats from the state board of education become involved in the approval process for specific waivers from rules and regulations. Section $72-1906 \mathrm{~F}$ requires the state board of education to approve, deny, or amend the application for waivers.

Section 72-1910B again reinforces the idea that charter schools are accountable to the district board, not to parents or performance standards. 
At the conclusion of each school year in which a charter school is operated in a school district, the board of education of the school district shall evaluate the impact the charter school has had on the educational system of the district and submit the evaluation to the state board of education. The state board shall review, assess and compile the evaluations of charter schools submitted by boards of education and shall submit the compilation of evaluations and other relevant material, including specification of school district and state board waivers granted with respect to the operation of each charter school, to the governor and the legislature. $(\$ 72-1910 \mathrm{~B})$

Being accountable to performance standards or to consumers are not major emphases of the Kansas statute. For the most part, Kansas charter schools rely on traditional bureaucratic reporting and compliance. Many of the freedoms promised by advocates and enjoyed by other states' charters are clearly absent here.

\section{PERFORM OR PERISH: MINNESOTA}

In 1993, Minnesota was the first state to pass charter school legislation. Their statute limits the sponsorship of charter schools to established educational entities such as school boards, school districts, private colleges, community colleges, technical colleges, state universities, and the University of Minnesota. Charter contracts are not to exceed 3 years but are renewable upon state approval (Minnesota Statutes, 2000).

Subdivision 1 of the charter school law (124D.10) identifies six main purposes of the legislation. The first purpose on the list is to "improve student learning." It is evident that Minnesota requires their charter schools to produce tangible results. First and foremost, they require them to demonstrate evidence of improved student achievement:

Subdivision 10. Pupil performance. A charter school must design its programs to at least meet the outcomes adopted by the commissioner for public school students. In the absence of the commissioner's requirements, the school must meet the outcomes contained in the contract with the sponsor. The achievement levels of the outcomes contained in the contract may exceed the achievement levels of any outcomes adopted by the commissioner for public school students. (Minnesota Statutes, 2000)

Although Minnesota asks its charter schools to demonstrate performance outside of the state requirements for public schools, it assists charter schools in this pursuit. The Department of Children, Families \& Learning (DCFL) 
has developed an accountability framework, which delineates expectations for charter school accountability and helps charter schools develop their own data gathering plan (Charter School Accountability Framework, 2000).

The accountability framework identifies five general categories of indicators of performance: financial resources, profile of teaching staff, student background, student participation, and statewide testing results. The framework pays particular attention to test score data, as these indicators are highly visible and attract considerable attention. The framework suggests numerous "measurable outcomes" that charter schools can consider when developing their own evaluation plans, but again places considerable emphasis on standardized tests:

Each charter school, with it's [sic] sponsor, should determine the specifics of their accountability model, and which nationally normed, standardized tests are most appropriate for their use. (Charter School Accountability Framework, 2000)

Finally, Minnesota takes performance accountability to another level. Although there is a distinct emphasis on student performance, performance accountability is not limited to indicators of student achievement. Various other student and school performance indicators are included. For example, among the suggested measurable nonacademic goals are indicators of presence and participation, citizenship, and personal-social adjustment.

\section{DISCUSSION}

Our analysis of state legislative documents opened us to a new perspective on bureaucratic, performance, and market accountability. We began to look at the origin and evaluative quality of the criteria under these accountability structures.

The origins of the accountability criteria are either established by the charter or sponsor (i.e., internally) or by some entity other than the charter or sponsor (i.e., externally). Consider bureaucratic accountability, which by most accounts in the literature involves the adherence to rules and regulations put forth by a governing body. Our inspection of state charter statutes indicated that such rules and regulations are typically set externally-usually by the state itself. Under performance accountability, accountability criteria are, in most cases, also externally imposed. For instance, charter schools are often judged by their performance on state-mandated exams. One of the exceptions 
was presented in the Minnesota case, where the charter or sponsor determines the standards for performance. Lastly, under market accountability, there are really no explicit, commonly agreed on criteria. Parents and students privately establish their own criteria by which to judge their own schools. The market mechanism relies on the consumer making the decision about a product, but no product information is deemed more important than any other. Again, no product criteria are overtly identified by the consumer; it is purely a private decision and one left to personal preference. Even the producer (the charter school) is not privy to the desires of its consumers.

Holding schools accountable requires that there are criteria by which to judge them. In the public sense, we have struggled with ways to evaluate school performance. Identifying worthy and valid criteria of accountability has indeed proved to be a challenge. Partly as a consequence, we rely heavily on bureaucratic forms of accountability. Bureaucratic inputs are empirical, well defined, and openly visible. Although not without limits, this form of accountability carries additional value in that it serves to protect children and the taxpayers. Under performance accountability, there is a direct attempt to measure school performance. However, valid indicators of school performance are difficult to come by. Even when they are established, there may be disagreement over the value of such criteria for judging a school. This in part justifies market forms of accountability.

Market accountability can be viewed as an alternative to bureaucratic and performance accountability, though as we argue below, perhaps it would be better to view it as complementary. Market accountability leaves the criteria of accountability in the hands of the consumer-a consumer who may or may not be adequately informed or who may or may not be misled by indicators of questionable validity. In fact, the term consumer may be too narrowly defined here. A consumer of public education is more than the parent or student. The taxpayers and general public also consume the products and by-products of public schooling (e.g., an educated citizenry, a strong economy, etc.). It stands to reason that this constituency also deserves a say in how schools are held accountable. Leaving it exclusively to parents and students to hold their schools accountable results in a parochial set of accountability criteria. This argument does not diminish the value of parental preference; rather, it serves to reinforce the meaning of public in public schools.

It might be best for states to construct accountability systems that incorporate several forms of accountability. The bureaucratic, performance, and market models can be complementary to one another (see Kirp, 1982; Kirst, 1990). Furthermore, using multiple forms of accountability serves to expand and strengthen an accountability system (Darling-Hammond, 1989). State charter school policies that rely predominantly on the market to gauge charter 
school performance may not effectively purge mismanaged or inadequately performing schools. States that add substantial bureaucratic regulations may stifle innovations by overwhelming charter school administrators with reporting requirements, leaving them little time to think about academic improvements. And relying solely on performance components may force charter schools to teach to narrowly defined performance indicators. States that blend multiple models of accountability better inform all constituentsincluding parents and taxpayers-about the performance of publicly funded schools. This, we believe, can be done without sacrificing autonomy or innovation.

\section{REFERENCES}

Arizona Revised Statute §15-183, §15-185 [Online]. (2000). Retrieved September 25, 2000, from the World Wide Web: http://www.azleg.state.az.us/ars/15/183.htm

Budde, R. (1988). Education by charter: Restructuring school districts, key to long-term continuing improvement in American education. Andover, MA: Regional Laboratory for Educational Improvement of the Northeast \& Islands.

Center for Education Reform. (2000). Charter school legislation: State rankings [Online]. Retrieved May 18, 1998, from the World Wide Web: http://edreform.com/laws/ranking.htm

Charter School Accountability Framework [Online]. (2000). Retrieved September 25, 2000, from the World Wide Web: http://cfl.state.mn.us/charter/accountability.pdf

Chubb, J. E., \& Moe, T. M. (1988). What price democracy? Politics, markets and American schools. Washington, DC: The Brookings Institution.

Cronbach, L. J. (1991). Functional evaluation design for a world of political accommodation. In W. R. Shadish, T. D. Cook, \& L. C. Leviton (Eds.), Foundations of program evaluation: Theories of practice (pp. 323-376). Newbury Park, CA: Sage.

Darling-Hammond, L. (1988, Winter). Accountability and teacher professionalism. American Educator, 8-13, 38-43.

Darling-Hammond, L. (1989, Fall). Accountability for professional practice. Teachers College Record, 91(1), 59-80.

Dorn, S. (1998). The political legacy of school accountability systems. Education Policy Analysis Archives, [Online] 6(1). Retrieved March 2, 1998, from the World Wide Web: http://olam. ed.asu.edu/epaa/v6n1/

Flake, J. L. (1995, August 26). Odd view of accountability. The Arizona Republic, p. B6.

Garn, G. A. (2000). Moving from bureaucratic to market accountability: The problem of imperfect information. Manuscript submitted for publication.

Gintis, H. (1995). The political economy of school choice. Teachers College Record, 96(3), $492-511$.

Glass, G. V. (1972, June). The many faces of educational accountability: What is genuine accountability and what is sham? Phi Delta Kappan, 53, 636-639.

Glasser, B. G., \& Strauss, A. L. (1967). The discovery of grounded theory: Strategies for qualitative research. New York: Aldine de Gruyter. 
Hartley, M. (1995, August 20). Accountability missing from charter schools. The Arizona Republic, p. E3.

House, E. R. (1993). Professional evaluation: Social impact and political consequences. Newbury Park, CA: Sage.

Kansas Revised Statute \$72-1904, \$72-1905, \$72-1906, §72-1910 [Online]. (2000). Retrieved September 1, 2000, from the World Wide Web: http://www.ksbe.state.ks.us/charter/ law.html

Kirp, D. (1982). Professionalization as a policy choice. World Politics, 34(2), 137-174.

Kirst, M. (1990). Accountability: Implications for state and local policymakers. Washington, DC: U.S. Department of Education, Office of Educational Research and Improvement, Information Services.

Levin, H. (1974). A conceptual framework for accountability in education. School Review, 82 , 363-391.

Miles, M. B., \& Huberman, A. M. (1994). An expanded sourcebook: Qualitative data analysis (2nd ed.). Thousand Oaks, CA: Sage.

Minnesota Statutes [Online]. (2000). Retrieved September 25, 2000, from the World Wide Web: http://www.revisor.leg.state.mn.us/stats/124D/10.html

Rivera, M. J. (1994). Accountability and educational reform in Rochester, New York (Doctoral dissertation, Harvard University, 1994). Dissertation Abstracts International. (University Microfilms No. 9432425)

Shadish, W. R., Jr., Cook, T. D., \& Leviton, L. C. (Eds.). (1991). Foundations of program evaluation: Theories of practice. Newbury Park, CA: Sage.

Shanker, A. (1988). Restructuring our schools. Peabody Journal of Education, 65(3), 88-100.

Smith, M. S. (1988). Educational indicators. Phi Delta Kappan, 69(7), 487-491.

Winthrop, H. (1975, January). Accountability in education via a policy-making and planning orientation. Peabody Journal of Education, 52, 127-134.

Wohlstetter, P. (1991). Accountability mechanisms for state education reform: Some organizational alternatives. Educational Evaluation and Policy Analysis, 13(1), 31-48. 